\title{
Elections and the dilemma of indigenous Fijian political unity
}

\author{
Alumita Durutalo
}

The notion of indigenous Fijian political unity was a social construction which emerged after the establishment of the colonial state in 1874 . Within Fijian society itself, the idea of political unity was adopted from indigenous forms of knowledge in which the philosophy of unity was embodied in customary leadership practices within the context of sociopolitical constructs such as the I tokatoka, mataqali, yavusa, vanua and matanitu. ${ }^{1}$ The colonial administration under Sir Arthur Gordon reinterpreted and adopted these indigenous forms as a basis for national unity under the colonial state. Underlying the new approach was 'the colonial myth of homogeneity' (Routledge 1975:220) which proposed that there was a single form of cultural reality with uniform chiefly rule amongst indigenous Fijians in the different vanua throughout Fiji. British restructuring of Fijian social structures was facilitated by the system of 'indirect rule' involving the blending of the old and new systems of leadership under the authority of chiefs. The colonial government ruled Fijians through their chiefs (Durutalo 1997:66-7).

The introduction of indirect rule and the creation of various institutions to support it, resulted in the evolution of communal politics of which political unity has been the most essential aspect. The Fijian version of communal politics involves the process of politicking and competition for power which remains exclusive within a community which utilises traditional loyalties, ceremonies and values to solicit political support. Within indigenous Fijian communities, traditional loyalties to chiefs and the vanua became the foundation for political support to the chiefs and hence to the colonial state. The result was the emergence of patron-client politics. $^{2}$

\section{The colonial state and the politics of clientelism}

Clientelism emerged through the system of indirect rule. Sir Arthur Gordon's Native (Fijian) Administration did more than preserve the Fijian 
'race and culture'; it radically restructured relations in Fijian society. The major power brokers within the native administration were members of the Native Council (subsequently the Great Council of Chiefs) which sat at the apex of the institution. Members of the Council were mostly eastern Fijian chiefs and other commoners who were co-opted as officials in the Native administration. The native administration also included other structures such as the provincial governments, the Native Lands Commission (NLC) and (much later) the Native Land Trust Board (NLTB). All these structures had within them persons or 'lesser brokers' who were also answerable to the colonial state through the various layers of ranks which were above them. Within each yasana or province, for example, were a hierarchy of posts which began with the Roko Tui $i^{4}$ at the provincial level to the Turaga ni Koro ${ }^{5}$ (village headman) at the village level.

Fijian unity under the colonial state was imagined to have a neat hierarchy, at the apex of which was a chief who dictated to the assumed 'lesser' chiefs and commoners. The colonial state's restructuring of the chiefly system arrested a once dynamic institution where leaders had to earn the role and respect they were accorded. What emerged out of the system of indirect rule through the native administration was a very hierarchical institution which progressively became more powerful and authoritarian for the majority of the ruled. The system also gave rise to the 'new type of chief' ${ }^{\prime 6}$ whose political supremacy was based on his loyalty to the colonial state which reciprocally supported him. That is,

The colonial state, through the entrenchment of Indirect rule, created and maintained a patron-client relationship as a means of reaching grassroot[s] people...the creation of the Fijian administration in colonial Fiji served other important purposes than 'protecting' the Fijians; they were a direct link, through clientelism to the grassroot people. Those who controlled the colonial state needed political support... and confidence from indigenous Fijians (Durutalo 1997:50).

At Fiji's independence in 1970, the various administrative structures which had supported indirect rule were entrenched in the 1970 Constitution, including a communal or ethnically based electoral system. Both the former Alliance Party (from 1970 to 1987), and the Council of Chiefs-backed Soqosoqo ni Vakavulewa ni Taukei (SVT) Party ${ }^{8}$ (from 1991 onwards), utilised the massive network of patron-client politics through the Fijian Administration.

\section{The Alliance Party and indigenous Fijian political unity}

Amongst indigenous Fijians, the strength of the eastern Fijian-dominated Alliance Party lay in the system of Fijian administration. The party depended on the Fijian administration network for its survival. Communal 
patronage within the system had enabled the survival of the Alliance Party from independence in 1970 to the coups in 1987. For the Fijians, the party attempted to maintain the allegiance of all the groups in both the traditional and modern sectors, under the Council of Chiefs. On the multiethnic front, the party attracted mainly prominent Indo-Fijian business class and the European and the Chinese business community. At one end of the political spectrum then, was the effort to maintain indigenous Fijian allegiance through patron-client politics, and on the other, the maintenance of the multiethnic allegiance within the free market system.

Indigenous Fijian political unity under the Alliance reinforced obedience from those below to those at the top echelons of power and assumed the protection of indigenous rights and values through structures such as the Great Council of Chiefs, the NLC and the NLTB. However, the onslaught of modernity and the consequent demand for democracy at all levels contributed to the deconstruction of indigenous Fijian political unity. During its 17 years, the Alliance Party camouflaged class interests with ethnicity. Grassroots Fijians within the party supported an élite multiethnic group who were more accessible to the free market and its benefits than to them. This evolving class structure was supported by the unity of the 'have nots' (in modern economic terms), who had contributed significantly to the emergence of contradictions within the Alliance Party. The composition of the party was 'politically volatile' because ethnic Fijian grassroot unity was used to support class interests. The defeat of the Alliance Party and its reappearance as the SVT exposed and led to other forms of contradictions within Fijian society.

At the intra-societal level, contradictions also emerged from the continued trend of traditional political rivalry between eastern and western Fiji. This rivalry can be defined in terms of 'internal colonialism' (Durutalo 1995) where the colonial state, since its inception, had favoured the eastern chiefly establishment for its role in stabilising the rule of the state through patron-client politics. This contributed to the dominance of eastern chiefs in the governance of the indigenous Fijians through employment in the native administration and the civil service. Chiefs in the more egalitarian vanua in western Viti Levu, have always regarded themselves as independent from eastern Fijian hegemony since they were never conquered by them prior to colonisation. Fiji's political history, therefore, reveals that western Fijian chiefs and their people have always shown an independent attitude towards the eastern Fijian oligarchy and their dominance in the new patron-client politics. Political dissent such as that shown by Apolosi Nawai and alternative Fijian political parties have always emerged in western Viti Levu. In the post-1987 era, the formation of alternative Fijian political parties has exposed the dilemma of Fijian political unity. 


\section{The deconstruction of an orthodoxy}

The deconstruction of indigenous Fijian political unity continued in the postcolonial era. In the late 1970s, the Western United Front (WUF) was formed by western Fijian landowners after a conflict with the Alliance government over the payment of forest royalty, western Fijian chiefs claiming that their resources were being used without equitable compensation in monetary terms or otherwise. Within the realm of Fijian politics, the formation of the WUF was seen as a reaction against the eastern establishment. The western Fijian chiefs and their people saw their politicoeconomic marginalisation from the colonial to the postcolonial era, as similar to those of the descendants of the indentured labourers (girmityas). In this context, both were ruled by a government dominated by eastern Fijian élites and Fiji's ruling class. This was the beginning of a political consciousness which transcended the ethnic divide.

Challenge to Alliance rule and the orthodoxy of unity did not emerge only in western Viti Levu. Earlier in 1974, the ultra-right wing Fijian Nationalist Party (FNP) was formed by Sakeasi Butadroka of the province of Rewa. While indigenous Fijians in the WUF based their politico-economic marginalisation on traditional rivalry and the dominance of eastern Fijian chiefs within the colonial and postcolonial state, Butadroka argued that the Alliance Government was conceding too much to other ethnic groups while doing little for indigenous Fijians. The Fijian nationalists assumed that the presence of other ethnic groups was the cause of their economic marginalisation.

In the April 1977 general elections, Butadroka was able to sway about 25 per cent of Fijian communal votes away from the Alliance Party, causing its defeat. However, the Alliance was appointed to a minority government by the Governor General Ratu Sir George Cakobau when the National Federation Party (NFP), which had narrowly won the election, was unable to form government. In the second (September) elections of 1977, the Alliance was returned to power with a big majority. Two factors contributed to its victory. These were the split of the NFP into two factions, and the fear of Indian domination which was fanned by the nationalists and which contributed to the Alliance's victory. The 'fear of the unknown' was employed to rekindle Fijian political unity.

The most formidable threat to Alliance rule came with the formation of the Fiji Labour Party (FLP) in 1985. Its formation marked a new era in Fiji's history when an element of class consciousness was used by trade union leaders as a basis for forming a political party. Trade union leaders and workers who were members of the party, became conscious of economic exploitation across the ethnic divide and the use of ethnic politics to conceal class exploitation. The formation of the party posed a long-term challenge 
to ethnic politics in Fiji, especially in an era of increasing globalisation. The specific impetus behind the formation of the party lay in the IMF-required austerity measures in 1984-85 which recommended deregulation of the labour market, reduction in the size of government, a freeze on the expansion of the civil service posts, a wage freeze, privatisation of parastatals, and removal of price controls and subsidies (Durutalo 1996:134-5).

The multiethnic base of the party threatened a variety of interests. First and foremost, it threatened the Alliance Party and its dominant ruling class, including the Indo-Fijian business class, Chinese, Europeans and the indigenous Fijian chiefly and commoner élite. At another level, the FLP was a threat to the indigenous Fijian chiefly élite (mostly from eastern Fiji) who, since cession, had claimed custodianship of indigenous values and interests. The leadership of the FLP by a western Fijian (Dr Timoci Bavadra) was not only a threat to eastern Fijian political dominance but also to the facade of indigenous Fijian political unity maintained under the Alliance Party. The formation of the FLP, at a critical period of the Cold War, also threatened Fiji's allies (internal and external), who subscribed to the free market paradigm. The Weekend Australian (28-9 March 1987) described the Alliance Party as

basically a conservative government...closely allied to the United States and Australia, in particular, and...solidly pro-Western and anticommunist. It welcomes American warships without asking questions, and has close defence links with Australia. It is seen as a pillar of Western interests in the South Pacific, and a powerful impediment against Soviet encroachments (in Lawson 1991:248).

Sitiveni Rabuka saw the formation of the FLP as 'foreign to the Fijian political scene and indicative of a trend towards socialism; they were, to him, warnings of an alarming change of direction in Fiji's national and international politics' (Dean and Ritova 1988:46).

This supports the Weekend Australian's thesis and reflects the real interests behind the existence of the Alliance Party. It also exposed a number of things: the intricate links between a Third World postcolonial political party and western free market interests; and how grassroots indigenous Fijian voters in the Alliance Party were used to support a government with class interests that linked the internal (local) to the external (international).

\section{The 1987 military coups and indigenous fijlan political unity}

The coup-maker, Lt Colonel Sitiveni Rabuka, explained that the military coups of 1987 were aimed at reinforcing chiefly leadership and protecting indigenous Fijian interests. He argued that

the election of the Bavadra Government...had involved a leakage of

Fijian votes to the coalition parties. This was... a reflection of a 
changing society...[and] a breaking down of Fijian society and values. Young Fijians were ignoring or defying the old values, their chiefs and their elders (Dean and Ritova 1988:33).

The first major flaw in this argument was the claim that only young Fijians had deserted the Alliance Party. In fact, as already seen, many high chiefs had also over time defied the party. A high chief of Ba province whom I interviewed in 1996 argued that the 'Fiji Labour Party election victory in 1987 was not bad at all. A number of chiefs from various vanua also supported the party' (Durutalo 1997:169). The second major weakness was the failure to define 'values' for all Fijians. It was evident that Rabuka assumed that all Fijians in different sociopolitical and economic groupings had the same values. The question that one should pose is 'what are Fijian values and is voting for another party a reflection of a breakdown in values or changing values?' Furthermore, when we talk about Fijian values, are we referring to pre-European values, missionary values or colonially created values?

This line of argument has been undermined with the SVT's defeat in the 1999 general elections, and with the emergence of many Fijian parties which challenged and undercut its power base. Perhaps indigenous Fijians are looking for the type of political leadership which offers them more than the empty rhetoric of protecting values. The coups brought to the fore many contradictions within Fijian society itself. The first may have been the exposure of the 'myth of homogeneity'. Political leadership was originally the domain of a few and was maintained through the monopoly of power in patron-client politics. The reaction against it led to other reactions such as the invocation of independent vanua feelings. This, in turn, has rekindled the pre-colonial political independence of Fijians in the context of their vanua and leadership of their chiefs. The problem which arises, then, is one of 'competing legitimacy's and is part of the general problem of trying to maintain unity in many Third World postcolonial states where previously unity under the colonial state was maintained through the 'invention of tradition' and the adoption of the 'myth of homogeneity'.

The coups themselves have been a catalyst for rapid social change amongst indigenous Fijians, unleashing many forms of intra-societal rivalry. Since the early 1990s western Viti Levu chiefs have met to discuss the formation of yasayasa Vaka-Ra or western confederacy. This in itself implied a number of things. First and foremost the chiefs wanted to reaffirm the pre-colonial independence of the western Fijians, who were never conquered by the eastern chiefs who now dominate them. Even eastern Fiji did not have an overall hierarchical structure which everyone accepted or understood. The colonial state introduced this through the Fijian administration and its patron-client political system. 
Amongst Fijians themselves, there are different levels of rivalry. Within each province there are subtle forms of competition based on pre-colonial vanua independence. In each province, for example, there are certain vanua which receive more from government than others. In the province of Nadroga and Navosa, the coastal Nadroga people have always been favoured over the inland Navosa people in terms of state resources for any development in the province. This has been a trend from the early days of colonisation when the Navosa people used to defy both missionary and colonial leadership. This has currently led to the move by the Navosa people to form their own province. ${ }^{10}$

At another level of rivalry, the various vanua on Viti Levu have increasingly regarded the arrival of people from the maritime provinces as a threat to their resources in what may be a milder form of the tension between the Guadalcanal and Malaitans in Solomon Islands. This was increasingly felt after the coups when the Viti Levu people realised that leadership after the coups only served to strengthen the political power of Fijians from Vanua Levu, Lau (the Tovata Confederacy), and other smaller islands, which contributed to the overwhelming support given to the Fijian Association Party (FAP) and other rival parties to the SVT on the big island of Viti Levu (see Tables 5.2 and 5.3).

In Tailevu, rivalry between the SVT and the FAP reached into chiefly households. With the change in constituency boundaries, Tailevu has been demarcated into two communal constituencies, namely Tailevu North and Tailevu South, and two open constituencies, Tailevu North/Ovalau and the Tailevu South/Lomaiviti. A number of prominent chiefs from the province competed against each other for the four seats. On the chiefly island of Bau itself, Adi Litia Cakobau (of the Mataiwelagi household), was the SVT candidate for the Tailevu North/Ovalau open seat and her cousin Ratu Tu'uakitau Cokanauto (of the Naisogolaca household), stood for the FAP, ${ }^{11}$ and won the seat. In the Tailevu South communal seat and Tailevu South/Lomaiviti open seat, both SVT candidates lost to FAP and the FLP candidates respectively. One of the SVT candidates who lost was Ratu Apenisa Cakobau of the chiefly Mataiwelagi family. This trend of chiefly rivalry in party politics is recent. Perhaps, rivalry amongst chiefly households has always existed but was dormant until the increasing participation of indigenous Fijians in party politics.

At another level, the aftermath of the coups and the rise in the level of corruption and nepotism in government was not only blatant to Indo-Fijians and other ethnic groups but to indigenous Fijians as well, especially to those who did not support the coups. Perhaps the collapse of the National Bank of Fiji due to bad debts (by those close to people in power) epitomised the gravity of the problem. ${ }^{12}$ A chief from the province of Tailevu who was interviewed in 1996 on his views on Fijian political unity argued that 
Politicians use the notion of political unity as a basis of building their own wealth. If you look at the names of the bad debtors from the National Bank of Fiji, some of those involved hold a dual role of being a government minister as well as being a traditional chief. These people use both their modern and traditional roles as a means of earning money for themselves (Durutalo 1997:165).

Such practices unfolded the class nature of the coups and reaffirmed the truth that there was more to the coups than the ethnic explanations suggested. If some people benefited from the coups, the most crucial question to ask is which group of indigenous Fijians and people of other ethnic origins benefited?

\section{The 1990 Constitution, and the SVT}

The SVT was established in 1991 with the blessing of the Bose Levu Vakaturaga (Great Council of Chiefs). ${ }^{13}$ The formation of the SVT was a deliberate and urgent attempt by the Fijian ruling élite to defend their status as the only defenders and promoters of ethnic Fijian values and interests. This move was seen by its supporters as crucial in a climate of increasing Fijian political dissent. The SVT, like its predecessor, the Alliance Party, was to utilise patron-client politics through the Fijian administration, which implied theoretically, that all indigenous Fijians registered in the Native Lands Commission' $\mathrm{s}^{14}$ Vula ni Kawa Bula (VKB) ${ }^{15}$ were already members of the new party. Furthermore, the move was aimed at blocking the formation of any other indigenous Fijian political party.

The involvement of the Great Council of Chiefs and the Fijian administration in the formation of the SVT was enough to give the party a 'legitimate' look for most Fijians who over the years have come to internalise the myth of cultural homogeneity. A Malolo chief in the province of Nadroga who was interviewed in January 1996, explained the basis of his support for the SVT Party along 'legitimacy' lines: 'I support the SVT because it is a chiefly party. Other political parties are not part of the Fijian leadership system' (Durutalo 1997:166). However, the new party was not supported by all Fijians. A number of vanua chiefs in western Viti Levu viewed the move as another attempt by the eastern Fijian chiefly élite to retain political dominance. A high chief in the vanua Vatulevu of Nadi, whom I interviewed in January 1996, echoed this sentiment

The formation of the SVT was done by those in the top echelons of power in eastern Fiji. The formation of the SVT Party followed by various meetings was always done in Suva and never once were meetings decentralised to western Fiji. This is in spite of the fact that all [the] major resources that the Fiji government depends on are to be found in western Fiji. It is most obvious that the survival of the Fiji 
government is not determined by some coconut plantations on the island of Lakeba [in the province of Lau]. However, when it comes to government leadership, eastern Fijians dominate (Durutalo 1997:158).

The use of the Fijian administration as a political power base for the SVT was a deliberate attempt to infiltrate those vanua which otherwise would not have subscribed to the party. By doing this, the founders of the party exploited an institution which was supposed to be for the overall development of indigenous Fijians regardless of party affiliation. Indigenous Fijians from the 14 provinces who did not affiliate with the SVT Party saw this move as a blatant case of authoritarianism and abuse of power. A Fijian from Tailevu who was interviewed in 1996 argued that

The use of the provincial offices to promote SVT agenda is not right because it contradicts the purpose that the provinces were set up for... as an integrative force amongst indigenous Fijians... What will happen is provincial service to the people will be neglected at the expense of preaching political propaganda (Duratalo 1997:179).

Along the same lines, a highly educated Fijian from Cakaudrove, and who was a minister in the Chaudhry government, had the following to say about the future of the Great Council of Chiefs in party politics

That there is a clear distinction between an involvement in traditional politics and an involvement in party politics. Chiefs involvement in party politics implies that they support a political party as against other political parties...Increasingly, chiefs will alienate themselves from Fijians who do not support the party...If SVT falls, chiefs will fall with it. Inevitably their forming SVT is short sighted. By forming a political party, they are undermining their own traditional positions as chiefs (Duratalo 1997:177).

The 1990 Constitution was an attempt to recreate the rules to enable election victory and political dominance of the traditional élite. Out of the 37 indigenous Fijian seats, 32 seats were derived from the 14 provinces as shown in Table 5.1.

Underlying the 'over-allocation' of Fijian seats to the provincial constituencies was the belief that Fijians in the informal or rural sector of the Fijian society were still politically naive and easier to control than those in the formal or urban sector. This is part of a characteristic of patronclient politics where the patrons exploit the ignorance of the voters for political gain. The electoral arrangement under the 1990 Constitution with its wholly communal and first-past-the-post voting system had indeed enabled overwhelming victory for the SVT Party in the 1994 general elections. Table 5.2 shows the details of the votes polled in these elections for the Fijian provincial and Fijian urban constituencies. 


\begin{tabular}{|c|c|}
\hline Table 5.1 & members in provincial constituencies \\
\hline Province & Number of seats \\
\hline $\mathrm{Ba}$ & 3 \\
\hline Bua & 2 \\
\hline Cakaudrove & 3 \\
\hline Kadavu & 2 \\
\hline Lau & 3 \\
\hline Lomaiviti & 2 \\
\hline Macuata & 2 \\
\hline Nadroga/Navosa & 2 \\
\hline Naitasiri & 2 \\
\hline Namosi & 2 \\
\hline Ra & 2 \\
\hline Rewa & 2 \\
\hline Serua & 2 \\
\hline Tailevu & 3 \\
\hline \multicolumn{2}{|c|}{$\begin{array}{l}\text { Notes: There are } 14 \text { provinces in Fiji: } 8 \text { are on the island of Viti Levu (Ra, Ba, Nadroga, Serua, } \\
\text { Namosi, Rewa, Naitasiri, and Tailevu); } 3 \text { are on the island of Vanua Levu and surrounding islands } \\
\text { (Cakaudrove, Bua and Macuata); Lomaiviti is composed of the islands in the centre of Fiji; Lau is } \\
\text { made up of the eastern-most islands; and the island of Kadavu is the southern-most province. The } \\
\text { boundaries of some of these provinces have been redrawn over the years, especially during the } \\
\text { colonial period. }\end{array}$} \\
\hline \multicolumn{2}{|c|}{$\begin{array}{l}\text { Source: Durutalo, A.L. 1997. Provincialism and the crisis of indigenous Fijian political unity, } \\
\text { unpublished MA thesis, Centre for Development Studies, School of Social and Economic }\end{array}$} \\
\hline
\end{tabular}

Despite the landslide, the victory of the SVT Party created its own dynamics and led to demands for change. For Fijians in the formal sector, the 1990 electoral system represented a gross under-representation of the majority of the Fijian taxpayers, with only four seats. The move was selfdefeating both for SVT and the Great Council of Chiefs because later, Fijians moved out and formed alternative political parties. This may have been a direct reaction to the unequal distribution of parliamentary seats in the Fijian constituencies.

The formation of the All National Congress (ANC) in the early 1990s was one way in which the internal contradictions about the 1987 coups manifested itself. Maverick veteran politician and strong Taukei Movement supporter from western Viti Levu, Apisai Tora, applied political shrewdness when he formed the ANC Party. He distanced himself from the SVT and formed the ANC as an alternative Fijian political party. However, the ANC managed to secure only one seat in the 1994 general elections. Also in the early 1990 s a more formidable political force was created by the late Josevata Kamikamica. The Fijian Association Party (FAP) was formed by a breakaway faction of the SVT which did not support the 1994 Budget, 
Table 5.2 Votes polled by political parties in the 1994 general elections

\begin{tabular}{lrrrrrrrrr} 
Fijian provincial & Valid & \multicolumn{1}{c}{ SVT } & FAP & \multicolumn{1}{c}{ FNP } & ANC & FLP & STV & NDP & IND \\
constituencies & votes & \multicolumn{1}{c}{$\%$} & \multicolumn{1}{c}{$\%$} & \multicolumn{1}{c}{$\%$} & \multicolumn{1}{c}{$\%$} & $\%$ & $\%$ & $\%$ & $\%$ \\
Ba & 11,769 & 55.8 & 2.8 & 1.1 & 40.3 & - & - & - & - \\
Bua & 4,428 & 88.2 & 2.8 & 1.2 & - & - & - & - & 7.8 \\
Cakaudrove & 10,550 & 93.3 & 6.7 & - & - & - & - & - & - \\
Kadavu & 3,855 & 96.9 & 2.2 & 0.9 & - & - & - & - & - \\
Lau & 4,957 & 41.9 & 57.8 & 0.4 & - & - & - & - & - \\
Lomaiviti & 4,815 & 84.6 & 2.8 & 4.1 & - & - & - & - & 8.5 \\
Macuata & 5,283 & 91.2 & 6.2 & 2.5 & - & - & - & - & - \\
Nadroga/Navosa & 8,719 & 48.5 & - & - & 13.9 & - & 37.5 & - & - \\
Naitasiri & 6,866 & 40.0 & 52.8 & 7.2 & - & - & - & - & - \\
Namosi & 1,650 & 80.2 & - & 17.4 & - & - & - & - & 2.3 \\
Ra & 5,392 & 24.9 & 2.6 & 18.2 & - & - & 2.4 & - & 51.9 \\
Rewa & 3,616 & 52.6 & 6.6 & 32.6 & 0.7 & - & - & - & 8.2 \\
Serua & 2,250 & 58.3 & - & 25.7 & 10.7 & - & - & 0.97 & 4.3 \\
Tailevu & 9,879 & 48.1 & 29.1 & 18.9 & 0.8 & - & - & - & 3.1 \\
Total & 84,029 & 62.7 & 14.5 & 6.8 & 8.4 & 0.1 & 3.2 & 0.02 & 4.3 \\
Fijian urban & & & & & & & & & \\
constituencies & & & & & & & & & \\
Suva City & 8,085 & 7.20 & 21.6 & 3.9 & 2.4 & - & - & - & - \\
Serua/Rewa & 3,441 & 68.0 & 23.9 & 4.0 & 2.6 & - & - & - & 1.4 \\
West & & & & & & & & & \\
Tailevu/Naitasiri & 9,977 & 69.9 & 25.1 & - & 4.9 & - & - & - & - \\
Western Urban & 6,008 & 61.7 & 12.0 & 5.8 & 8.6 & 5.1 & - & - & 6.9 \\
Total & 27,511 & 68.5 & 21.1 & 2.9 & 4.7 & 1.1 & - & -1.7 \\
Grand total & 111,540 & 63.4 & 15.3 & 6.3 & 8.0 & 0.2 & 2.8 & 0.02 & 4.0
\end{tabular}

Note: SVT - Soqosoqo ni Vakavulewa ni Taukei; FAP_Fijian Association Party; FNP_Fijian Nationalist Party; ANC - All National Congress; FLP_Fiji Labour Party; SVT_-Soqosoqo ni Taukei ni Vanua; NDP - National Democratic Party; IND—Independents.

Source: Electoral Commission Report for 1 January 1994-31 December 1996.

leading to its defeat. Kamikamica and other members of the FAP had been concerned with Rabuka's poor leadership style generally. Kamikamica argued that Rabuka

took over a role that he has not had the experience for, particularly civilian leadership because he's been in the army most of his working life. The principles and style of leadership in a democratic environment is different from the military...It [leadership] shouldn't really be a problem if you have some idea of what you're doing (The Review February 1994:25).

Rabuka's economic leadership was also considered a total failure by his critics. This had been a major factor in the defeat of the 1994 Budget. Kamikamica explained 
Take the budget. He [Rabuka] could have resolved that very simply...I faced a similar situation when he handed [the government] over after the coups. He didn't hand over because he respected the chiefs. He handed over when the economy was completely down. He couldn't establish our trading and diplomatic links with other countries...from the way he was carrying on-it was like a political time bomb (The Review February 1994:25).

One of the major concerns of the FAP was to restore economic growth, resolve the Agricultural Landlord and Tenants Act (ALTA) issue, and review the 1990 Constitution.

\section{The 1995 Constitutional Review and its impact on Fijian political unity}

In 1995, the government established a Constitution Review Commission to review the 1990 Constitution. The Commission recommended major changes to Fiji's electoral system, including compulsory registration of voters, compulsory voting, the adoption of an Alternative Vote (AV) system in place of the first-past-the-post system and the introduction of open (nonracial) seats. The Commission identified the following as advantageous features of the alternative voting system: encouragement of multiethnic government; recognition of the role of political parties; incentives for moderation and cooperation across ethnic lines; effective representation of constituents; effective voter participation; effective representation of minority and special interest groups; fairness between political parties; effective government; effective opposition; proven workability; and legitimacy (Rigamoto 1999:1-2).

The new changes incorporated into the new Constitution posed a direct challenge to Fijian political unity labouring under the myth of homogeneity. The review of the 1990 Constitution alienated ardent Taukei supporters of the coups who believed that the review itself had undermined the whole purpose of the coups-which was supposed to be the entrenchment of Fijian interests. A message that emanated from the coups and which some politically naive Fijians fell for is that Fijians should be aided without work. This was clear in the type of leadership that Rabuka had demonstrated to Fijians and for which his supporters gave him their support. As Kamikamica, in The Review, explained: 'He [Rabuka], cannot have everything his own way. Since the coups, he's had the habit of taking whatever he wants...He should work for what he takes and not simply take it because he has the power' (The Review February 1994:24).

Demands of the new economic system and the failure in the delivery of goods to the clients contributed to the erosion of the SVT's power base during the 1999 elections. The implementation of structural adjustment 
policies, which included public sector reforms, the move towards privatisation, and the 'logical' use of money in an increasingly free market society, was perhaps beyond the comprehension of grass root Fijian supporters of the coups. What Fijians did not understand is that, if the coups were really for Fijians, then why were many Fijians the poorer in the end?

In a discussion with Fijian Vatuwaqa squatters in Suva before the 1999 general elections, a Fijian woman said that she and her family and some other fellow squatters supported the Fiji Labour Party in 1987 and are still supporting it now in the hope of improving their living conditions. The woman believed that the party could devise policies to cater for the poor (interview with author, March 1999 Suva). For these marginalised Fijians, who have become part of the modern urban community, the choice of a political party is pragmatic and need-driven. Political pragmatism was also evident in the voting pattern of the SVT supporters. In the Kadavu Fijian provincial communal constituency, Jim Ah Koy, a Fijian Chinese millionaire of the SVT party, was elected overwhelmingly because of his business acumen and his contribution to development in his mother's province. Ah Koy secured the largest percentage of Fijian votes ( 83.40 per cent) in all the 23 Fijian communal seats (Fiji Times 20 May 1999:25).

Table 5.3 shows votes polled by Fijian political parties in the 1999 General elections.

\section{Analysis of the 1999 elections and the formation of altermative political parties as an expression of Fijian political dissent}

Perhaps the most outstanding feature of postcolonial and post-1987 politics within Fijian society has been the continuous demonstration of political dissent towards the ruling élite's ideology of unity. Dissent by Fijians such as Apolosi R. Nawai in the early years of this century are linked to the current general dissent in Fijian thinking now expressed through the formation of alternative Fijian political parties. Earlier forms of dissent were suppressed by the colonial state because the social construction of unity was aimed at ensuring the survival of the modern state in a society which previously had independent chiefdoms. Attempts to suppress Fijian independent political thinking were continued in the postcolonial era by the Fijian ruling élite. Rabuka's military coups can be viewed in that light. The irony is that the coups, which were aimed at reinforcing the myth of homogeneity through political unity, only served to encourage the growth of independent political thinking.

In the 1999 general elections, there were at least eight Fijian political parties, apart from candidates who stood independently. These were the: 
Table $5.3 \quad$ Votes polled by political parties in the 1999 general elections

\begin{tabular}{|c|c|c|c|c|c|c|c|c|c|}
\hline $\begin{array}{l}\text { Fijian provincial } \\
\text { constituencies }\end{array}$ & $\begin{array}{l}\text { Valid } \\
\text { votes }\end{array}$ & $\begin{array}{c}\text { SVT } \\
\%\end{array}$ & $\begin{array}{l}\text { FAP } \\
\%\end{array}$ & $\begin{array}{c}\text { NVTLP } \\
\%\end{array}$ & $\begin{array}{l}\text { VLV } \\
\%\end{array}$ & $\begin{array}{l}\text { PANU } \\
\%\end{array}$ & $\begin{array}{c}\text { FLP } \\
\%\end{array}$ & $\underset{\%}{\text { COIN }}$ & $\begin{array}{l}\text { IND } \\
\%\end{array}$ \\
\hline Bua & 5,330 & 20.09 & - & 4.38 & 54.37 & - & - & 20.77 & - \\
\hline Kadavu & 4,987 & 83.40 & 9.81 & - & 6.80 & - & - & - & \\
\hline Lau & 5,927 & 47.51 & - & - & 50.82 & - & - & - & \\
\hline Lomaiviti & 6,361 & 22.0 & - & - & - & - & 23.4 & - & 54.6 \\
\hline Macuata & 7,926 & 46.29 & - & - & 53.71 & - & - & - & . \\
\hline Nadroga/Navosa & 13,071 & 41.05 & 50.65 & - & - & - & - & - & - \\
\hline Naitasiri & 8,992 & - & 71.21 & 28.79 & - & - & - & - & - \\
\hline Namosi & 2,315 & 43.41 & 56.54 & - & - & - & - & - & - \\
\hline $\mathrm{Ra}$ & 7,811 & - & - & 47.02 & - & 52.98 & - & - & - \\
\hline Rewa & 5,193 & - & 59.70 & 40.30 & - & - & - & - & - \\
\hline Serua & 3,345 & 37.28 & - & 62.72 & . & - & - & - & - \\
\hline Ba East & 8,398 & 34.9 & . & 5.66 & 6.88 & 52.55 & - & - & - \\
\hline Ba West & 10,052 & 34.47 & - & - & - & 63.53 & - & - & - \\
\hline Tailevu North & 7,449 & 53.63 & 46.36 & - & - & - & - & - & - \\
\hline Tailevu South & 7,110 & 40.38 & 53.59 & 6.03 & - & - & - & - & - \\
\hline Cakaudrove East & 6,582 & 78.01 & - & - & 16.70 & - & - & - & - \\
\hline Cakaudrove West & 7,920 & 68.94 & 6.94 & - & 24.1 & - & & - & - \\
\hline No. of seats won & & 4 & 5 & 1 & 3 & 3 & - & - & 1 \\
\hline \multicolumn{10}{|l|}{$\begin{array}{l}\text { Fijian urban } \\
\text { constituencies }\end{array}$} \\
\hline North East & 10,182 & 68.94 & 6.94 & - & 24.1 & - & - & - & 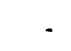 \\
\hline North West & 12,342 & 32.77 & - & - & - & 67.23 & - & - & - \\
\hline South West & 9,475 & 43.24 & 56.76 & - & - & - & - & - & - \\
\hline Suva City & 9,191 & 42.22 & 57.78 & - & - & - & - & - & \\
\hline Tamavua/Laucala & 10,014 & 45.19 & 54.81 & - & - & - & $\cdot$ & - & \\
\hline Nasinu & 9,096 & 49.57 & 50.42 & - & - & - & - & - & \\
\hline No. of seats won & & 1 & 4 & $\cdot$ & - & 1 & - & - & \\
\hline
\end{tabular}

Note: SVT-Soqosoqo ni Vakavulewa ni Taukei; FAP-Fijian Association Party; NVTLP-Nationalist Vanua Tako/Lavo Party; VLV-Veitokani Ni Lewenivanua Vakaristo; PANU-Party of National Unity; FLP-Fiji Labour Party; COIN-Coalition of Independent Nationals; IND-Independents.

Source: Fiji Times 20 May 1999.

Soqosoqo ni Vakavulewa ni Taukei (SVT), Fijian Association Party (FAP), Veitokani ni Lewenivanua Vakarisito (VLV), Nationalist Vanua Tako/Lavo Party (NVTLP), Party of National Unity (PANU), Party of the Truth (POTT), Viti Levu Dynamic Multiracial Democratic Party (DMDP), and the Fiji Labour Party (FLP). The most immediate impact of the emergence of these parties has been the defeat of the SVT.

\section{The implications of SVT defeat}

The results of the 1999 general elections have been devastating to the Great Council of Chiefs-sponsored SVT Party. Of the 23 Fijian provincial and urban communal constituencies, it won only five, whilst the Fijian 
Association Party won nine, PANU four, VLV three and NVTLP and Independent one each. Communal Fijian seats are an indicator of political legitimacy amongst indigenous Fijians. In this respect, the future of the SVT as well as 'chiefs in politics' has been marginalised. What was interesting in the 1999 general elections as far as Fijian politics is concerned, was not the percentage of votes that the SVT still controled overall, but the number of Fijian political parties which emerged to counter the 'legitimacy claim' of the SVT.

A number of questions have emerged in light of the defeat of the SVT: What is the future of Fijian political unity under patron-client politics? Has the defeat of the SVT spelled the beginning of the end of patron-client politics? Or have alternative parties simply taken it over on a smaller scale? Will the marginalisation of the SVT have an impact on the political power of the chiefly council? Will this in turn affect chiefly leadership as a whole? What about the role of the power brokers whose interests are closely linked with the maintenance of the status quo? Will they experiment with other political strategies to enable their political survival? Perhaps the recent resignation of former Prime Minister Rabuka from his parliamentary seat to become the president of the Great Council of Chiefs partially answers this question. Will the Great Council of Chiefs now operate along the system which is adopted in modern party politics? Will the council accommodate dissenting political views? How will this affect its traditional leadership roles? Are Fijians seeing the beginning of the acceptance of liberal democracy as a permanent part of Fijian politics?

\section{The impact of the re-allocation of Fijian provincial and urban seats}

The re-drawing of Fiji's electoral boundaries under the new electoral system has resulted in the overall reduction of communal seats in favour of open seats. Fijian provincial communal seats have been reduced from 32 to 17 while Fijian urban seats have been increased from 3 to 6 . These changes have been accompanied by the overall redrawing of some constituency boundaries in line with five separate electoral rolls: for Fijian voters, IndoFijians, Rotumans, general electors, and an open roll which allows for multiethnic voting. The redrawing of the boundaries has had an impact on the redistribution of power within Fijian society. At one level the reduction of provincial seats has implied tougher competition in terms of Fijian political representation in parliament. Representation has been rationalised in terms of province size and population distribution and not political favouritism, which in the past resulted in small provinces like Lau having three parliamentary seats whilst bigger population bases such as Nadroga/ Navosa had two seats. Within each province, therefore, the process of selecting candidates has become more competitive. 
In the redrawing of provincial boundaries, the three large provinces of Cakaudrove, $\mathrm{Ba}$ and Tailevu have been divided into two separate constituencies each and this has had an impact on the distribution of power in general at the intra-provincial level. In Tailevu, for example, there is now a Tailevu North provincial constituency and a Tailevu South Fijian provincial constituency. The division has affected provincial politics in the following ways. The basis of patron-client politics which had influenced the dominance of one or two vanua in party politics, since political independence, has been challenged. Bauan dominance was challenged with the defeat of two chiefly candidates: Adi Litia Cakobau (for the Tailevu North/Ovalau Open Constituency), and Ratu Apenisa Cakobau (for the Tailevu South/Lomaiviti Open Constituency). There has been a 'battle of the chiefs' kind of scenario amongst different parties in the two Tailevu constituencies. For instance, in the Tailevu North/Ovalau Open Constituency, cousins Ratu Tu'uakitau Cokanauto represented the FAP, and Adi Litia Cakobau represented the SVT. Ratu Cokanauto won. In the Tailevu South/Lomaiviti Open seat, Ratu Isireli Vuibau of the Fiji Labour Party defeated Ratu Apenisa Cakobau of the SVT.

In some subtle ways, party politics has served to aggravate traditional chiefly rivalry either in terms of household conflicts or vanua conflicts, influencing the support that each group has for different political parties. In Tailevu before the 1999 general elections, a Fijian Association Party candidate reminded the villagers that the SVT Party had undermined the contribution and the traditional leadership of the Tailevu people during its reign. This campaign reinforced that general feeling, causing the defeat of three SVT candidates in the province, including two from the chiefly Cakobau family. This may also have been because

the province [Tailevu] had not had much of a part in the various regimes since the May coup, which had been dominated by native Fijians from further north and east (Macuata, Cakaudrove, Lau) and soldiers from the province had been lukewarm in their support for Rabuka (Howard 1989:30).

Tailevu was not the only province which changed its party preference in the 1999 general elections. In Viti Levu as a whole, the SVT managed to win only 1 out of the 23 Fijian communal seats. The defeat could be explained in terms of the reaction of the Viti Levu people in general, against the socioeconomic and political performance of the SVT government since its second term in power in 1994. Apart from its economic performance, many vanua on Viti Levu felt that since the coups and the formation of the SVT Party, Fijian politics had been dominated by people from Vanua Levu and other islands. Only two provinces which supported the SVT overwhelmingly in the 1999 elections were Cakaudrove (Rabuka's province) 
and Kadavu (Ah Koy's). One was a coup-maker and the other a very rich business man.

\section{The role of 'seasonal parties' and alternative parties in Fijian politics}

In the 1999 elections, the SVT Party was challenged by the emergence of 'seasonal parties' and the re-strengthening of alternative Fijian political parties.

Seasonal parties can be understood in terms of responses to needs that arise at a particular point in time. They act as indicators of 'independent thinking' among Fijians and use the modern political system to express dissent from the dominant mainstream political ideology of unity. Since Independence in 1970 seasonal political parties, as alternatives to the eastern Viti Levu dominated Fijian political parties, have always emerged in western Viti Levu. In the 1960s, Apisai Tora formed the National Democratic Party. This was a conservative indigenous Fijian party based on a similar political ideology to that of Butadroka's Fijian Nationalist Party. This party later merged with the Indo-Fijian dominated Federation Party, giving it the name National Federation Party (NFP). Tora was a member of the NFP when the party won the 1977 general elections. Another western Viti Levu seasonal party which emerged in the late 1970s to challenge the power of the eastern Fijian oligarchy was Ratu Osea Gavidi's Western United Front (WUF). In the early 1990s the All National Congress (ANC) emerged in western Viti Levu and led by Tora, himself an 'all seasons' western Fijian politician. In 1998 Tora formed the Party of National Unity (PANU), sponsored by the Ba Provincial Council. While the party won 4 out of the 23 Fijian Communal seats in parliament, Tora himself again failed to secure a parliamentary seat. Nonetheless, the idea behind the formation of the PANU has once again challenged the political power base of the SVT in western Viti Levu. In the 1999 general elections, the SVT failed to secure any Fijian communal seats in western Viti Levu. Sakeasi Butadroka's FNP failed to attract many followers, while the FAP won 9 of the 23 Fijian provincial and urban constituencies (see Table 5.3).

Towards the end of 1998, the Veitokani ni Lewenivanua Vakarisito (VLV), or the Christian Democratic Party, was formed by another breakaway group of the SVT Party. Former Methodist Church President, Reverend Manasa Lasaro, and other church members from mostly Vanua Levu and Lau fell out with Sitiveni Rabuka and this led to the formation of the VLV. While the party's support appears to be concentrated in the province of Lau and on Vanua Levu, this nevertheless poses a direct challenge to the political power base of the SVT in eastern Fiji as a whole. The Methodist Church has facilitated the survival of the eastern Fijian chiefly hegemony since its arrival in Fiji in 1835. One of the foremost tasks of the church was to 
legitimate the role of chiefs in traditional Fijian society because it depended on the cooperation of the people through their chiefs for its survival. The formation of a political party through the church is a direct attack on one of the main tenets of Fijian unity which is supposed to be grounded in the trinity of vanua, lotu, and matanitu. ${ }^{16}$ In the 1999 general elections the VLV won three Fijian communal seats.

\section{Conclusion}

The myth of homogeneity has been constantly challenged since the establishment of the colonial state in 1874. Since Independence in 1970, challenge to eastern Fijian hegemony has been aggravated by the involvement of Fijians in party politics. Fijians have challenged the basis of unity under the colonial and postcolonial state and its ensuing patronclient politics by establishing seasonal or alternative Fijian political parties. Political dissent was regarded as a threat by those whose interests the system safeguarded. Over the years, unequal relationships in the form of chiefs dominating commoners or the eastern region dominating the western region have been entrenched. The 1987 coups can be viewed as a desperate attempt to re-strengthen the old order with its modern class interests. The coups, however, only served to throw up contradictions in a society whose unity was enabled through the formation of the modern state. The 1999 elections saw the re-emergence of pre-colonial vanua under the guise of alternative Fijian parties, including the FAP, the VLV and PANU.

Elections have always exposed the fragility and dilemma of Fijian political unity. The formation of vanua-based parties post-1987 continues a long term trend in Fijian political development. With the constitutionalisation of a multiparty cabinet, each regional party may attempt to forge a coalition with other parties of similar sociopolitical and economic interests. Perhaps, the present coalition in government has already set the pace for this new political development within Fijian society. The trend on the whole has imposed a permanent challenge to the colonial myth of homogeneity and the interests it used to protect since the formation of the colonial state.

\section{Notes}

1 Itokatoka is an extended family unit which is traced patrilineally. In some parts of Fiji the same extended family unit was known as the bito or batinilovo. Customary land use and tenure was mostly based on this kinship unit in pre-colonial Fiji (see France 1969). Matagali is a sub-clan which is composed of one or more I tokatoka. It was made the basic landowning unit by the colonial government (see France 1969). Yavusa is the largest kinship group within the Fijian social system. It is composed of one or more mataqali. The word yavusa is derived from yavu which implies 'house 
foundation'. The members of a yavusa are believed to have originated from a common house foundation and hence a common ancestor. A number of yavusa make up a vanua. In modern day Fiji, a number of yavusa would be found in a number of villages within a vanua. A vanua is a political construct which has been unified through warfare. A vanua chief therefore rules in a specific geographical boundary. Matanitu refers to the confederacy or the highest political formation beyond the 'vanua'. It was found in some parts of Fiji towards the end of the eighteeth century. Unlike the more stable Yavusa, formed out of kinship alliances, the matanitu were composed of fragile alliances. They were formed through political processes and were regarded as power constructs articulated through the use of force. Currently there are only three recognised Matanitu in Fiji which are Kubuna, Burebasaga and Tovata. There were many more in pre-colonial Fiji.

2 Clapham (1985:59) argued that patron-client politics is founded on a premise of inequality between patrons and clients. Clients only benefit if they have anything to offer and it can also serve to intensify ethnic conflicts. Through patron-client politics, the roads are built in the wrong place or the wrong person gets the job, etc. Conservative Fijian historians tend to highlight Sir Arthur Gordon's creation of the Native (later Fijian) Administration purely as an attempt to preserve the Fijian race and its culture. However, what they have not discussed is why it was necessary to have done this in terms of the establishment of the colonial state and its ensuing colonial capitalism.

4 This was and is the highest post within the provincial administration. Since the creation of provinces, most Roko Tui have been traditional chiefs. Such posts within the Native Administration facilitated the emergence of the 'new type of chief'. Since the creation of provinces in 1874, there has never been a female Roko Tui in Fiji. The words Roko Tui are two related Fijian words which are associated with the chiefly institution. Roko is a title which is conferred on people (including males and females) of chiefly birth in some parts of Fiji such as the various vanua in the province of Lau. Tui simply means chief; for instance, Tui Levuka or chief of Levuka.

5 This is the provincial administrator at the village level. Many chiefs refused to accept this post at the village level because they viewed it as a 'servant type' of job.

6 The concept of the 'new type of chief' began with the employment of chiefs in the system of indirect rule. Such chiefs thus assumed a dual role of being a traditional chief and that of being a 'state chief'. The chief's new role reinforced his traditional basis or rule and strengthened his political power.

7 The Alliance Party was formed in 1966. The party had three major ethnic components, namely the Fijian Association, the Indian Alliance and the General Electors. It was a unique political arrangement in which the concept of 'multi-racialism' was maintained through ethnic politics. The Fijian Association arm of the Alliance party was held together by patron-client politics through the Fijian Administration.

8 The SVT (roughly translated into English as 'the Fijian law making' party), was formed in 1991 as a replacement for the Fijian Association arm of the Alliance Party. The Great Council of Chiefs backed the formation of this party. Its major aims were to preserve the eastern Fijian chiefly hegemony which had emerged since the establishment of the colonial state; to contain Fijian political unity under this hegemony; and to re-strengthen the Fijian administration and its patron-client politics. 
9 The Political situation within Fijian society in the post-coup era is one of 'competing legitimacy'. New political parties, for instance, have emerged from different regions of the country and have been supported by the various vanua and chiefs within the party. Each party defends its own rights to be the 'legitimate' representative of indigenous Fijians. This has been the case with the formation of the Party of National Unity (PANU) in western Viti Levu and the formation of the Veitokani ni Lewenilotu Vakarisito (VLV or the Christian Democrats), by mostly Methodist Church members in Vanua Levu.

10 Since the Labour Coalition government assumed leadership after the 1999 general elections, the people of Navosa had officially requested the Deputy Prime Minister and Minister for Fijian Affairs, Adi Kuini Vuikaba (a high chief of Navosa), to make Navosa a province of its own. The colonial government had put Nadroga and Navosa together to form a province. In this union, Navosa had always been neglected in terms of development.

11 Mataiwelagi is the sacred house foundation (Yavu Tabu) of the chiefly Cakobau family, which seats at the apex of the Kubuna Confederacy. Amongst the eastern Fijian confederacies of Kubuna, Burebasaga and Tovata, Kubuna is highest in rank. Naisogolaca is another chiefly household foundation whose members are closely related to the Mataiwelagi household.

12 The failure of the Government-owned National Bank of Fiji was perhaps the biggest blunder of the Rabuka government. Various cronies of the coups benefited through loans from the bank which after the coup was managed by a 'Rabuka handpicked Rotuman General Manager'. Such corruption revealed the real purpose of the coups (see The Review July 1995).

13 The Bose Levu Vakaturaga (Great Council of Chiefs or GCC) was initially created as the Native Council by Sir Arthur Gordon. It sits at the apex of the Native (Fijian) Administration. The Council was originally known as the 'Native Council' in 1874, then over the years it became the 'Council of Chiefs' and much later it had another name change to the 'Great Council of Chiefs'.

14 The Native Lands Commission was established under the Native Lands Ordinance in 1880. The NLC was to register all lands belonging to Native Fijians through some social unit. Thirty years later after many claims, and heated debates, G.V. Maxwell was able to draw up a Fijian land tenure system through the matagali as a social unit. The NLC still exists and has an extensive record of Fijian landholdings and the basis of claims which formed the land tenure system.

15 The NLC has records of VKB. Indigenous Fijian land claims are based on one's registry in the VKB or the Fijian genealogy. To qualify for entry, one must have had a Fijian father through marriage or otherwise and the father must have been a registered Fijian through the VKB. Children born out of wedlock of Fijian mothers also qualify, provided that their mother is registered in the VKB. These children are registered in their mothers' mataqali and become landowners too through their mothers.

16 Fijian Unity is based on vanua, lotu and matanitu. Vanua refers to customary chiefly rule within the context of Fijian culture; lotu refers to Christianity and its teachings and matanitu is the state. The formation of both the FAP and the VLV has been a threat to those whose interests have been protected by the vanua, lotu and matanitu thesis. The formation of the FAP implies the breaking up of the vanua; formation of the VLV means the breaking up of the lotu. 